This is an electronic reprint of the original article. This reprint may differ from the original in pagination and typographic detail.

Please cite the original version: P. Mantere, H. Lassila (2018) Competences of Teachers in Research, Development and Innovation Work at the Universities of Applied Sciences in Finland, ICERI2018 Proceedings, pp. 5508-5514.

doi: $10.21125 /$ iceri.2018.0228 


\title{
COMPETENCES OF TEACHERS IN RESEARCH, DEVELOPMENT AND INNOVATION WORK AT THE UNIVERSITIES OF APPLIED SCIENCES IN FINLAND
}

\author{
Päivi Mantere ${ }^{1}$, Hilkka Lassila ${ }^{2}$ \\ ${ }^{1}$ Laurea University of Applied Sciences (FINLAND) \\ ${ }^{2}$ Savonia University of Applied Sciences (FINLAND)
}

\begin{abstract}
One of the most important tasks for Universities of Applied Sciences (UAS) in Finland is to ensure a close connection between education and working life. According to the UAS law, the three main tasks of UASes are education, research and regional development. The amount of research, development and innovation work (RDI) is one of the parameters that regulate the funding of UAS functions.
\end{abstract}

In order to be able to correspond to the demand of development, it is crucial that the personnel at UASes are competent to carry out RDI work. They should have competencies, skills and knowledge about different methods and approaches as well as social and interaction skills, and a close relationship with working life that has the latest knowledge.

The Finnish Ministry of Education and Culture is financing a national project that aims to develop a new model for cooperation between UASes in Finland and confirm the role of UASes in the national innovation ecosystem. The project involves UASes, which are offering studies in tourism and hospitality management.

One aim of the project is to study the competences of UAS personnel concerning RDI skills and to find out how to improve RDI competences. The main focus of this paper is to describe 1) what kind of RDI work do the UAS personnel do, 2) what kind of knowledge and skills they have, and 3) what kind of lack of knowledge there is.

The study included a survey that was sent to the personnel in each Finnish UASes that teach tourism and hospitality management. The results of the study show that RDI work at UASes is multifaceted and complex and it requires a different kind of knowledge and skills. The informants have close relationship with working life and they have an excellent knowledge of the needs of their partners. The worst lack of knowledge was in operating at the international level.

The results will be used to develop skills and knowledge in RDI work among teachers and other personnel and for educating them and encouraging them to share knowledge and develop cooperation. The theoretical framework and literature review focuses on RDI work, competencies, skills, knowledge and co-operation with working life.

Keywords: RDI work, competencies, cooperation, hospitality management.

\section{INTRODUCTION}

Universities of Applied Sciences in Finland have a strong expertise in the areas of research, development and innovation, and they have an important role in the Finnish research and innovation system. The RDI activities of Universities of Applied Sciences are effective and multidisciplinary.

RDI activities usually have a strong interaction with working life: the results of the activities are practice-oriented and the enterprises can utilize the results while developing their business. In many cases, students participate in RDI work with working life. In addition, teachers and other personnel have a strong connection to working life and many of them have a long practical experience before their carrier at UAS.

The staff and students of UASes are actively involved in research and development. Projects are funded by national or EU funding instruments, and also private funding is becoming more common. $\mathrm{RDI}$ is partly implemented without funding or payment, for example with non-governmental and other non-profit organizations. 
One of the missions defined for the UASes in Finnish legislation is to carry out applied research and development activities that serve UAS education, support the world of work and regional development, and take the industrial structure of the region into account. [1]

An important feature of the RDI practice of the UASes is the emphasis on Bachelor level students in the institutional RDI activities. This involvement of Bachelor students improves RDI competences and skills of the involved students. On the other hand, collaboration increases the knowledge and innovation needs of the public and private sector project partners. [2]

Overall it can be argued that there is a lack of adequate competence for undertaking RDI activities at required level. Therefore, the actual integration of RDI into education often resembles practice-based development projects without any 'real' RDI dimension. [2]

The Rector's Conference of Finnish Universities of Applied Sciences, Arene, [3] has defined research, development and innovation work as follows:

Table 1 RDI work at UAS

\begin{tabular}{|c|c|c|}
\hline Research & Development & Innovation \\
\hline $\begin{array}{l}\text { - The goal is to produce new } \\
\text { research knowledge that } \\
\text { can be utilised. } \\
\text { - Applied research with } \\
\text { businesses and other } \\
\text { research organisations. } \\
\text { - Scientific and experimental } \\
\text { methods and research } \\
\text { ethics. } \\
\text { - Scientific publishing. } \\
\text { - Infrastructures and } \\
\text { environments that serve the } \\
\text { needs of research. }\end{array}$ & $\begin{array}{l}\text { - New, innovative activities } \\
\text { for finding solutions. } \\
\text { - Multi-disciplinary designed } \\
\text { new products, services and } \\
\text { concepts. } \\
\text { - Implementing research and } \\
\text { innovation activities and } \\
\text { maximising impact. } \\
\text { - Development of working life } \\
\text { and business. } \\
\text { - Regional, national and } \\
\text { international development. }\end{array}$ & $\begin{array}{l}\text { - Innovation of new products and } \\
\text { services. } \\
\text { - Commercialising innovation and } \\
\text { promoting entrepreneurship. } \\
\text { - University of Applied sciences } \\
\text { as an innovation booster in } \\
\text { ecosystems. } \\
\text { - Further R\&D processing in } \\
\text { collaboration with working life } \\
\text { and business. } \\
\text { - Utilising an open culture of } \\
\text { activities and experimentation. }\end{array}$ \\
\hline
\end{tabular}

The Finnish Ministry of Education and Culture has granted funding for a national project, which aims to develop a new model for co-creation and to strengthen the role of UASes in the national innovation ecosystem. It should improve business management and service management competences in the hospitality industry and competitiveness in the international operational environment. The name of this project is ReKey, Developing the education of Bachelors of Hospitality Management and business opportunities. The project is organized around the joint development of hospitality management studies and business.

\section{HOSPITALITY MANAGEMENT AND CO-CREATION IN THE CONTEXT OF THE RDI WORK}

Hospitality is the "friendly and generous reception and entertainment of guests and strangers". Hospitality is made up of two distinct services: the provision of overnight accommodation for people staying away from home and the provision of sustenance for people eating away from home. Hospitality is something that is, principally, commercially created for consumption. [4] The hospitality industry covers the provision of food, drink and accommodation in venues away from home. These services include everyday purposes as well as services to tourists. [5]

Hospitality is comprised of three main functional areas: accommodation, food and beverages and entertainment. Hospitality organisations operate within a network of service organisations that are interrelated and interdependent. It includes tour operators, travel agents, tourism organisations, travel and transport operators, leisure, recreation and entertainment venues, restaurants, bars, clubs, cafes, hotels, resorts, motels, camping grounds, B\&B's and hostels. [6] 
Hospitality consumption comprises multiple interactions, often with many people [7]. Guest involvement leads to co-creating the value and quality of the experience. If guests are involved in the design of the experience, they have the opportunity to co-create the experience before it happens. [8]. Co-creation is an essential approach both in the hospitality industry and in the co-operation between UASes and working life.

Co-creation means active involvement with end-users and other relevant parties in a development process. [9]. Value creation is based on unique personalised experiences. Aim of co-creation is to engage all actors, which enables high level of information processing. Process is ongoing and communication should be transparent and open. [10] Different stakeholders have active roles: service companies utilise co-creation in order to involve their customers, employees and other actors. When UASes aim to serve the needs of working life, better it is important to apply co-creative approach also in that collaboration.

Innovation system can be divided into basic and applied research, product development, commercialization and business (launching new products and services). UASes are focused on applied research while companies are mostly concentrated on development that is more practical. [11]. According to the survey made by Arene RDI actions in UASes include diverse characteristics that promote effectiveness and usability. RDI work is typically developed based on regional strengths and possibilities. Nevertheless, cooperation and interaction between different stakeholders, especially with working life is characteristic during the whole process: from the beginning to the implementation and exploitation of the results.[3]

A common strategic goal of the RDI activities of any UAS is to produce information and develop services based on applied research that serves to strengthen the competences and competitiveness of the public agencies and private business community in its region. Hospitality management studies are provided in 13 Universities of Applied Sciences around Finland. All these UASes are involved in the ReKey-project, which enabled the opportunity to gather information and data versatilly and nation widely. The people who are working at the UASes in RDI work are in different positions. Many of them are teachers who are working together with working life in different kind of projects. Diverse competences and vocational roles are required from the personnel.

Anderson and Jack [12] have examined the different roles of teachers and explain what attributes, qualities, skills and knowledge are required in their work. They present teachers' roles in a typology dividing them to four different vocational roles: professional, technician, artisan and artist (table 1). The teachers with professional role can deal with application of knowledge and they are analysing thoroughly special knowledge related to their subject. They also argue that theoretical knowledge might be a little bit problematic when working with enterprises.

Anderson and Jack [12] see that the role of technicians is more hands-on than a professional's role. It presents the informed use of practical skills and technicians can apply their knowledge for developing and solving the problems in working life. The third type, artisans, have the most practical, learning by doing-approach in their work. The artisan's role concentrates on getting things done. The artists are creative and dynamic. They can concentrate on subjects in a visionary way and understand qualities of feelings.

The roles, tasks and abilities are shown in the following table (table 2).

Table 2. Role typologies for teachers

\begin{tabular}{|l|l|l|}
\hline Role & Task & Ability \\
\hline Professional & $\begin{array}{l}\text { Analysis and application of judgement } \\
\text { to an informed knowledge base }\end{array}$ & $\begin{array}{l}\text { High level of theoretical knowledge and analytical } \\
\text { skills }\end{array}$ \\
\hline Technician & Skilled application of knowledge & Applied knowledge \\
\hline Artisan & Skills and task involvement & Application of skills \\
\hline Artist & Creativity and perception & $\begin{array}{l}\text { Ability to transpose and transfer from different } \\
\text { mediums }\end{array}$ \\
\hline
\end{tabular}




\section{METHODOLOGY}

ReKey project consists of eight work packages and all Finnish UASes with hospitality studies are involved in the project. Each work package includes an operational aspect but also information search, studies and research. UASes require that the impressiveness of the research, development and innovation should be strengthened. This study was done as a part of the project.

The authors of this article represent two Finnish UASes, which participate in ReKey project. One aim of the study was to find out the RDI competences of UAS personnel and ways to improve them. The focus was to describe 1) what kind of RDI work they do, 2) what kind of knowledge and skills they have, 3 ) what kind of lack of knowledge there is.

The data of the study was collected in the end of year 2017 by using a questionnaire, which was sent by email to the personnel of each of UASes in Finland that teach hospitality management. The electronic survey included background indicators, for example education, work experience and professional title. The RDI indicators were scaled from 1 to 5 . In addition, there were open questions in the questionnaire.

The number of total informants was about 120 persons. The names of informants were received from the actors who are working in this project. 64 persons answered the questionnaire, which means that the response rate was $53 \%$. The data was analysed with basic statistics methods by using excel tools.

\section{RESULTS}

\subsection{The background of responders}

The clear majority of the background of responders' education was Master's degree (52\%). The second most common were doctor's degrees, which was the education background of $23 \%$ of the respondents $(n=15) .14 \%$ of the respondents $(n=9)$ had a higher Bachelor's degree. The least common educational backgrounds were professional undergraduate degrees and lower university degrees.

The respondents had strong work experience in tourism and hospitality working life. Their work experience in tourism and hospitality management divided primarily into a maximum of 10 years of work experience or over 25 years of work experience. The majority of the respondents, $25 \%(n=15)$ had $0-5$ years of work experience in tourism and hospitality management. $23 \%$ of the respondents $(n=14)$ had $6-10$ years of work experience, and $23 \%$ of the respondents $(n=14)$ had over 25 years of work experience. The personnel working at UASes in Finland are required to have job experience from practical working life. The results indicate that many of the experts with long working experience are willing to work at UAS.

Almost half ( $45 \%)$ of respondents had participated in RDI work at UAS for more than 11 years, $27 \%$ had a work experience of 5-10 years in RDI work and the rest of them had under 5 years of RDI work experience.

Over half ( $55 \%$ ) of the responders' professional title was lecturer and $8 \%$ were part-time teachers. The rest of the responders had professional title, which refers to RDI work, for example RDI coordinator, RDI expert or project manager. The result presents that RDI work is also included in teacher's work and gives a possibility to work together with working life in diverse projects. The share of RDI work demonstrates that in most cases (65\%) respondents use less than $50 \%$ of their working hours per year in RDI work. Only $15 \%$ of the responders used more than $75 \%$ of their working hours doing RDI work.

\subsection{The strengths and skill shortages in RDI knowledge}

The competence of RDI work was measured with nine different skills included in RDI work. The respondents estimated their own skills. The scale was from 1 (pure) to 5 (excellent). The table shows the name of skills, averages of answers (Mean) and standard deviation (SD). The low SD of many propositions suggests homogeneity of respondents. 
Table 3. Competence of RDI work $(n=64)$

\begin{tabular}{|l|c|c|}
\hline & Mean & SD \\
\hline Project management skills & 4.2 & 0.8 \\
\hline Project skills as part of teaching & 4.1 & 0.8 \\
\hline Guidance skills of student's final thesis & 4.1. & 0.9 \\
\hline Qualitative research & 3.7 & 0.9 \\
\hline Innovation methods & 3.4 & 0.9 \\
\hline Project administration & 3.1 & 1.4 \\
\hline Quantitative research methods & 3.1 & 1.0 \\
\hline Domestic financing instruments & 2.8. & 1.3 \\
\hline International financial instruments & 2.0 & 1.0 \\
\hline
\end{tabular}

The results present that the strongest RDI knowledge in average is clearly in the categories of project management expertise, research skills, development skills and thesis guidance skills. The knowledge in these categories is almost excellent. Based on the answers the weakest knowledge is that of the international financial instruments and the knowledge of other external financial application processes. Innovation methods and qualitative research and development work methods are experienced to be well adopted.

Respondents were asked also to estimate their own RDI work including the propositions scaled from 1 (pure) to 5 (excellent). (=61). The mean has been mentioned in the parentheses.

According to the average of the responses, the best area of RDI work was a close cooperation with working life (4.0). The respondents had almost an excellent knowledge of the needs of the working life in hospitality industry (3.9) and they had a good readiness for building networks (3.9). They also felt that the results of their RDI work had produced new information or developed business (3.8). Also being involved in developing new products and services was better than average (3.7). The respondents evaluated also, that they already had good local networks (3.5).

The worst evaluations were given to the international networks in developing RDI work, and the perceived lack of time for developing the respondents' RDI skills (2.3). The training provided by the organization, aiming to support RDI work, was also perceived a little worse than average (2.8). They estimated also that they have not skills of their RDI work to operate at the international level (2.0).

During the research, the respondents were also asked to evaluate their own RDI knowledge's strengths and skill shortages with verbally open answers and they were asked to mention three strengths and skill shortages. The strongest RDI knowledge mentioned was project management, strong connections with stakeholders and networks in working life. The respondents also mentioned that they have good innovation and service design skills.

The clearly weakest categories were knowledge of national and international funding. Skill shortages were also recognized in project management and research skills. In addition, shortages regarding digitalization, use of time, resource and publishing arose.

When the educational background was compared with the knowledge of national or international financial instruments, it can be seen that the knowledge of national financial instruments is a stronger area as a whole. The results show that education has an impact on the knowledge of financial instruments. The respondents with doctor's degrees had the best knowledge in these areas, and the ones with higher Bachelor's degree had the least knowledge of the national financial instruments. Work experience in the industry also seems to have an impact on the knowledge in financial application processes. The respondents with work experience of 11-15 years in the hospitality industry had the best knowledge of national financial instruments. The ones that had been working in the industry for over 25 years felt that they had the least knowledge in this category.

The respondents were also asked to mention obstacles in RDI work, and ways to improve the work. The biggest obstacle perceived was the lack of time. The second biggest obstacle was the structural and administerial issues in the organization. The disjointedness of work is making cooperation with business more difficult. It was clear, that the most needed things were temporal resources, 
possibilities to be involved in co-operation and training that aims at improving knowledge regarding RDI work.

\section{CONCLUSIONS}

Teachers and other personnel who are working at UASs need to have mixed roles when working with different partners and they need many kinds of competencies. The results of that study confirm that the new teachership now and in the future will be more multifaceted and it requires a different kind of knowledge than earlier. Working in RDI work the role of teachers will be more holistic and include cooperating with partners in working life and funding operators.

The RDI tasks of respondents are complex and differ according to the respondents. Some RDI tasks are a natural part of teachers' work at UASs. In addition to that, projects with external funding require different kind of competences and specialization. Results prove that the strength of RDI is the cooperation and collaboration in projects together with working life. Teachers and other personnel have gained experiences from working life and many have solid and active relationships in their network.

According to the research, there was lack of international competences, especially in applying international project and project management in the international framework. International networks are not strong enough and the knowledge concerning the funding instruments are minor. Hence internationalization is an important part of actions and strategies at HEs, this lack should be taken into consideration. The results will be used to develop skills and knowledge in RDI work among teachers and other personnel and for educating them and encouraging them to share knowledge and develop cooperation.

The UASes should become more visible for their environment, particularly regarding what they have to offer for potential clients. More attention should be paid to unite the agendas of UASes and relevant partners, either through small scale bridging mechanisms or longer-term collaborative practices. More effort should be directed towards learning how to collaborate with partners in society. The results can be used in developing cooperation between universities and working life.

\section{REFERENCES}

[1] UAS act 9932/2014

[2] P. Maassen, J.Spaapen, O.Kallioinen, P. Keränen, M. Penttinen, R. Wiedenhofer \& M. Kajaste, Evaluation of research, development and innovation activities of Finnish universities of applied sciences. A Preliminary Report, Publications of the Finnish Higher Education Evaluation Council, 2011.

[3] Rector's Conference of Finnish Universities of Applied Sciences. Arene ry. Innovation, Development and Research. Report of the structural development of research, development and innovation activities of Universities of Applied Sciences. 2017.http://www.arene.fi/wpcontent/uploads/Raportit/2018/arene_innovation-development-andresearch_web.pdf?_t=1526901760

[4] B. Brotherton \& R.C. Wood, R.C. Hospitality management, Educating the future generation of service innovators in emerging markets, Los Angeles: Sage. 2008

[5] D. Fosket, P. Paskins. \& A. Pennington, The theory of hospitality and catering, London: Hodder education, 2016.

[6] J.A. Kandampully, Services management, The new paradigm in Hospitality, New Jersey, Pearson Education, 2007.

[7] A. Williams, Understanding the hospitality consumer, Oxford: Butterworth-Heinemann, 2002.

[8] R.C. Ford, M.C. Surman \& C.P. Heaton. Managing Quality Service in Hospitality, How organisations achieve excellence in the guest experience. Clifton Park, NY, Delmar Learning, 2012.

[9] S. Jansen \& M. Pieters, The 7 principles of complete co-creation, Amsterdam, BIS Publishers, 2017. 
[10] P. Chathoth, L, Altinay, R.J.Harrington, F. Okumus \& E.S.W. Chan. "Co-production versus cocreation: A process based continuum in the hotel service context", International Journal of Hospitality Management. 32, 11-20, 2013.

[11] V. Salminen \& K: Mikkelä, K. Yrittäjäekosysteemit kasvun ajurina. Polic Brief 1/2016. Valtioneuvoston selvitys- ja tutkimustoiminta, 2016.

[12] A.R. Anderson \& S.L.Jack. "Role typologies for enterprising education; he professional artisan? "Journal of Small Business and Enterprise development, 15(2), 259-273, 2008. 